\title{
Colicin E2 Expression in Lactobacillus brevis DT24, A Vaginal Probiotic Isolate, against Uropathogenic Escherichia coli
}

\author{
Disha Trivedi, Prasant Kumar Jena, and Sriram Seshadri \\ Institute of Science, Nirma University, Sarkhej-Gandhinagar Highway, Chharodi, Ahmedabad, Gujarat 382481, India \\ Correspondence should be addressed to Sriram Seshadri; sriram.seshadri@nirmauni.ac.in
}

Received 19 September 2013; Accepted 14 November 2013; Published 4 February 2014

Academic Editors: V. Serretta, Y. Sumino, and E. Yilmaz

Copyright (C) 2014 Disha Trivedi et al. This is an open access article distributed under the Creative Commons Attribution License, which permits unrestricted use, distribution, and reproduction in any medium, provided the original work is properly cited.

\begin{abstract}
Novel therapeutic approaches are needed to combat the urinary tract infection in women. During menstruation elevated protein concentration and increase in oxygen and carbon dioxide concentrations with decrease in vaginal Lactobacilli all together contribute to urinary tract infections. Lactobacillus species are a predominant member of the vaginal microflora and are critical in the prevention of a number of urogenital diseases. In order to increase antimicrobial potential of vaginal Lactobacilli, bacteriocin colicin E2 which has specific activity against uropathogenic Escherichia coli has been overexpressed in vaginal probiotic Lactobacillus brevis DT24. Recombinant Lactobacillus brevis DT24 expressing colicin E2 showed much higher inhibitory activity against uropathogenic Escherichia coli than wild type L. brevis DT24 in vitro. Efficacy of probiotic Lactobacillus brevis DT24 expressing colicin E2 protein is required for further in vivo evaluation.
\end{abstract}

\section{Introduction}

Urinary tract infection (UTI) is the most widespread infection in women worldwide after intestinal infection [1]. UTIs affect an estimated 1 out of 3 women before the age of 24 $[2,3]$. Up to 40 to $50 \%$ of the female population will develop a symptomatic UTI at some time during their lives $[2,3]$ or develop complicated UTIs [4]. Recurrent UTI (rUTI) is a common syndrome in young healthy women. Previous studies suggest that $27 \%$ to $44 \%$ of women, who experienced an initial UTI, develop rUTI $[5,6]$.

UTI has the potential for severe and life-threatening sequelae if left untreated or undertreated. Possible sequelae include pyelonephritis which can lead to renal scarring and sepsis [7]. UTI can be particularly dangerous in pregnant women in whom it has been shown that up to $50 \%$ of those with asymptomatic bacteriuria (ABU) leads to develop pyelonephritis. In addition, these women experience higher rates of intrauterine growth restriction and low birth weight infants. The presence of a UTI has also been shown to increase the risk of preterm labor, preterm birth, pregnancy-induced hypertension, preeclampsia, amnionitis, and anemia [8].
Escherichia coli are among the most significant human pathogens, responsible for up to $90 \%$ of all community acquired and almost $50 \%$ of nosocomial UTIs. E. coli is a ubiquitous human pathogen responsible for both community and hospital-acquired infections $[9,10]$. A number of virulence determinants facilitate the ability of uropathogenic E. coli to colonize the urinary tract and exert cytopathic effects, including type 1 fimbriae [11], P fimbriae [12], Dr adhesions [13], hemolysin $[14,15]$ cytotoxic necrotizing factor 1 [16], flagella [17], capsule polysaccharide [18], lipopolysaccharide $\mathrm{O}$ antigen [19], and TonB-dependent iron transport systems [20]. During UTI outer membrane proteins of uropathogenic E. coli like porins (OmpA, OmpC, OmpX, NmpC, and $\mathrm{LamB}$ ) and outer membrane assembly factors, including YaeT and YeaF, as well as nucleoside and vitamin B12 receptors Tsx and BtuB, are overexpressed [21].

Colicin E2 (ColE2) is a proteinaceous bacterial toxin produced by some strains of Escherichia coli that exhibits inhibitory activity against uropathogenic E. coli [22] via binding to an outer membrane receptor-the TonB-dependent vitamin B12 transporter, BtuB [23]. 
Earlier reports suggest that there is an increased antibiotic resistance in E. coli. Initially, resistance was limited to certain specific antibiotics, such as ampicillin or trimethoprim [24], but recently the horizon of resistance has expanded, with the emergence of broad resistance to third generation antibiotics [25-28].

Lactobacillus species are an important group of bacteria that inhabit the gastrointestinal tract and represent the predominant microorganism found in the healthy vaginal ecosystem [29-33], producing a variety of compounds [3438 ] that inhibit potentially pathogenic microorganisms. It is for this reason that Lactobacillus species have been studied as a potential probiotic for the prevention and treatment of urogenital disease in women [39-42]. During menstruation, the vaginal $\mathrm{pH}$ becomes neutral, most likely due to the influx of menses blood, which has a $\mathrm{pH}$ range of 6.9 to 7.2 [43]. In addition, menses blood in the vagina also results in an elevated protein concentration [43] and increase in oxygen and carbon dioxide concentrations [44], leading to decrease in vaginal Lactobacilli, which all contribute to colonization of uropathogenic E. coli which leads to UTIs [45-48].

As a means of increasing the antimicrobial capabilities of Lactobacillus species against uropathogenic E. coli (UPEC), probiotic L. brevis DT24, isolated from vagina of healthy women [49], was used for overexpression of colicin E2.

The objective of this study was to express ColE2 structural gene $c e a B$ and immunity gene $c e i B$ from $E$. coli into probiotic Lactobacillus brevis DT24, secreting colicin E2 to exclude a uropathogenic E. coli competitively and completely. In this study genetically engineered probiotic Lactobacillus brevis DT24 would exert its antimicrobial effect against the target pathogen directly through the expression of ColE2 gene and indirectly through beneficial properties inherent in probiotics.

\section{Materials and Methods}

2.1. Bacterial Strains, Plasmids, and Growth Conditions. Bacterial strains used in this study are listed in Table 1. Lactobacillus brevis DT24 (NCBI Accession no. JX163909) was routinely cultured in MRS broth (HiMedia, Mumbai) at $37^{\circ} \mathrm{C}$ for $48 \mathrm{~h}$. For the analysis of expression of colicin E2, recombinant strains were grown in basal MRS medium supplemented with 2\% xylose. Escherichia coli DH5 $\alpha$, Escherichia coli BL21 D3, and Escherichia coli NCTC 50133 were routinely cultured in Luria Bertani (LB) broth and agar at $37^{\circ} \mathrm{C}$ for 16 to $24 \mathrm{~h}$ and uropathogenic Escherichia coli MTCC 729 (Microbial Type Culture Collection, Chandigarh) was routinely cultured in nutrient broth and agar at $37^{\circ} \mathrm{C}$ for 16 to $24 \mathrm{~h}$. Chlorampheni$\mathrm{col}(\mathrm{Cm})$ and streptomycin (Stpr) were used for the selection of plasmids.

\subsection{DNA Manipulation, E. coli Competent Cell Preparation,} Transformation, and PCR. Plasmid DNA was isolated using GeneJet Plasmid Miniprep Kit as per instruction (Fermentas). DNA cloning and transformation procedures followed as previously described [51]. Restriction enzymes were purchased from New England Biolabs. Ligation was carried out by using Rapid Ligation Kit (Fermentas).
TABLE 1: Bacterial strains and plasmids used in this study.

\begin{tabular}{|c|c|c|}
\hline $\begin{array}{l}\text { Strains and } \\
\text { plasmids }\end{array}$ & Description & Source \\
\hline $\begin{array}{l}\text { Lactobacillus brevis } \\
\text { DT24 }\end{array}$ & $\begin{array}{l}\text { Probiotic vaginal } \\
\text { isolate }\end{array}$ & In this study \\
\hline $\begin{array}{l}\text { Escherichia coli } \\
\text { NCTC } 50133\end{array}$ & $\begin{array}{c}\text { Contains pColE2-P9, } \\
\text { produces colicin E2 }\end{array}$ & {$[50]$} \\
\hline $\begin{array}{l}\text { Escherichia coli } \\
\text { DH } 5 \alpha\end{array}$ & Transformation host & MTCC \\
\hline $\begin{array}{l}\text { Escherichia coli } \\
\text { BL21 D3 }\end{array}$ & Expression Host & MTCC \\
\hline Escherichia coli & Uropathogenic strain & MTCC \\
\hline Plasmids & Description & Source \\
\hline pSLP111.3 & $\begin{array}{c}\mathrm{Cm}^{\mathrm{r}}, \text { E. coli/LAB } \\
\text { shuttle vector } \\
\text { SlpA signal peptide }\end{array}$ & $\begin{array}{c}\text { Prof. Jos Seeger } \\
\text { Lactrys, The } \\
\text { Netherlands }\end{array}$ \\
\hline pColE2-P9 & $\begin{array}{c}\text { Stp }^{\mathrm{r}} \text {, vector for colicin } \\
\text { E2 }\end{array}$ & $\begin{array}{c}\text { E. coli Genetic } \\
\text { Stock Centre, Yale } \\
\text { University }\end{array}$ \\
\hline pSL-ColE2 & $\mathrm{Cm}^{\mathrm{r}}, \operatorname{SlpA}$, and ColE2 & In this study \\
\hline
\end{tabular}

2.3. Construction of Plasmids and Transformation of Lactobacillus. The expression plasmid pSLP111.3, a type of secretion expression vector containing SlpA as secretion signal and having a cell wall anchor domain, was kindly gifted by Prof. Jos Seegers (Falco Biotherapeutics, The Netherlands). Nucleic acid manipulation and cloning procedures was performed according to standard procedures [51].

Colicin E2 gene fragment of about $2.01 \mathrm{~kb}$ encoding the colicin E2 structural gene (ceaB) and colicin E2 immunity gene $c e i B$ was obtained from the plasmid pColE2-P9 (E. coli genetic resource centre, Yale University, USA) by polymerase chain reaction (PCR) amplification with the primers $5^{\prime}$-GGATCCATGAGCGGTGGCGAT-3' (forward) containing a BamHI site (underlined) and $5^{\prime}$-CTCGAGTCAGCCCTTTTAAATCCTGA-3' (reverse) containing an XhoI site (underlined). PCR conditions were as follows: 30 cycles of $30 \mathrm{~s}$ at $94^{\circ} \mathrm{C}, 30 \mathrm{~s}$ at $58^{\circ} \mathrm{C}$, and $2 \mathrm{~min} 20 \mathrm{~s}$ at $72^{\circ} \mathrm{C}$ after denaturing for $4 \mathrm{~min}$ at $94^{\circ} \mathrm{C}$.

The PCR product of colicin E2 gene was cleaved with Bam HI and XhoI restriction endonuclease and inserted into the corresponding sites of pPSL111.3 digested by BamHI and XhoI, respectively, giving rise to pSLP-ColE2 (Figure 1).

Electroporation of L. brevis DT24 was carried out as previously described [52] with some modifications. In brief, a 2\% inoculum of an overnight culture was grown in MRS medium supplemented with $1 \%$ glycine at $37^{\circ} \mathrm{C}$ until the OD660 of culture was 0.2 to 0.3 . The cells were harvested and washed twice with cold washing buffer $(5 \mathrm{mM}$ sodium phosphate $\mathrm{pH}$ 7.4 and $1 \mathrm{mM} \mathrm{MgCl}_{2}$ ). The cells were then resuspended to $1 \%$ of the original culture volume in a cold electroporation buffer ( $1 \mathrm{M}$ sucrose, $3 \mathrm{mM} \mathrm{MgCl}_{2}$ ). For electroporation, $45 \mu \mathrm{L}$ of the cell suspension was mixed with 50 to $500 \mathrm{ng}$ of plasmid DNA and subjected to $2.5 \mathrm{kV}, 200-^{\prime} \Omega$, and $25 \mu \mathrm{F}$ electric pulse in a $0.2 \mathrm{~cm}$ cuvette by using a Genepulser II electroporation system (Bio-Rad Lab). After the pulse, $450 \mu \mathrm{L}$ of cold MRS was immediately added to the cell suspension, kept on ice 


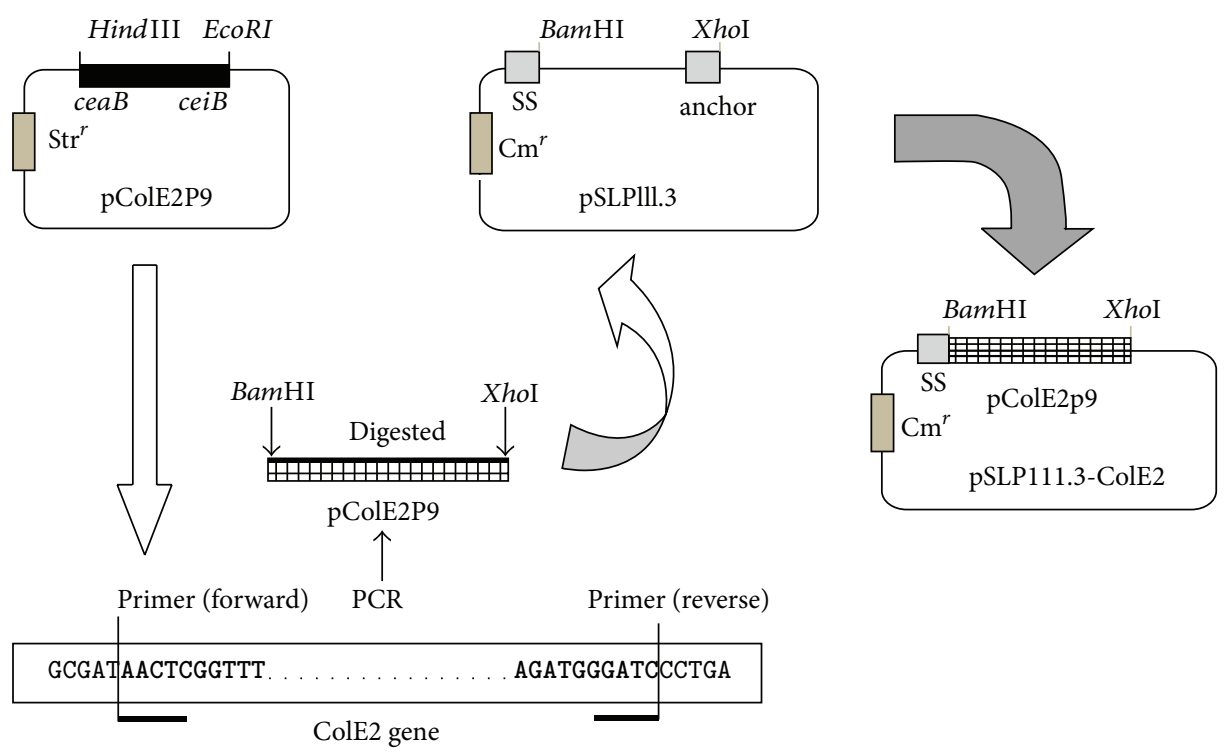

FIgURE 1: The construct of recombinant vectors expressing colicin E2. The ColE2 gene (ceaB) and its immunity gene (ceiB) on plasmid DNA (pCoLE2-P9) were amplified using the polymerase chain reaction (PCR) with the primers. The PCR product was cleaved with BamHI and XhoI restriction endonuclease and inserted into the corresponding sites of pSLP111.3, giving rise to pSLP111.3-pCoLE2-P9.

for $10 \mathrm{~min}$, and incubated for $3 \mathrm{~h}$ at $37^{\circ} \mathrm{C}$. The transformants were plated onto MRS agar plates and incubated for 48 to $72 \mathrm{~h}$. The transformation efficiency was calculated as the number of transformants per microgram of plasmid DNA.

\subsection{Molecular Weight Determination. Transformed ColE2} gene having Lactobacillus brevis DT24 was grown in MRS medium at $37^{\circ} \mathrm{C}$ for $24 \mathrm{hr}$ and centrifuged (10,000 rpm, $30 \mathrm{~min}$, and $4^{\circ} \mathrm{C}$ ) to collect supernatants. The collected supernatants were filter sterilized $(0.20 \mu \mathrm{m}$; Axiva). Ammonium sulfate was slowly added to the cell-free supernatants to $60 \%$ saturation and stirred for $4 \mathrm{~h}$ at $4^{\circ} \mathrm{C}$ and centrifuged $\left(10,000 \mathrm{rpm}, 30 \mathrm{~min}\right.$, and $\left.4^{\circ} \mathrm{C}\right)$. The precipitate was resuspended in $10 \mathrm{~mL}$ of $25 \mathrm{mM}$ ammonium acetate buffer $(\mathrm{pH}$ 6.5) and desalted by dialysis using a 1,000 Da cutoff dialysis membrane (Sigma) against the same buffer. Sodium dodecyl sulfate-polyacrylamide gel electrophoresis (SDS-PAGE) was used for further separation, as described by Laemmli [53].

\subsection{Antimicrobial Activity of Recombinant L. brevis DT24} Expressing Colicin E2. Antimicrobial activity of cell-free supernatant (filter sterilized) was measured by well diffusion assay. Filtrates were neutralized (set to $\mathrm{pH} 6.5$ ) with $5 \mathrm{~N}$ $\mathrm{NaOH}$. Nutrient agar plates were flooded with pathogenic bacteria $(0.1 \%$ of overnight grown uropathogenic E. coli strain), air-dried, and then $6 \mathrm{~mm}$ diameter wells were punctured in each plate. The prepared supernatants were poured into respective wells $(25 \mu \mathrm{L})$ and incubated for $24 \mathrm{~h}$ at $37^{\circ} \mathrm{C}$. L. brevis DT24 was used as negative control and E. coli NCTC 50133 was used as positive control.

\section{Results}

3.1. Construction of an Expression Vector. Plasmid pSLP111.1 is a high-copy-number plasmid which includes a constitutive

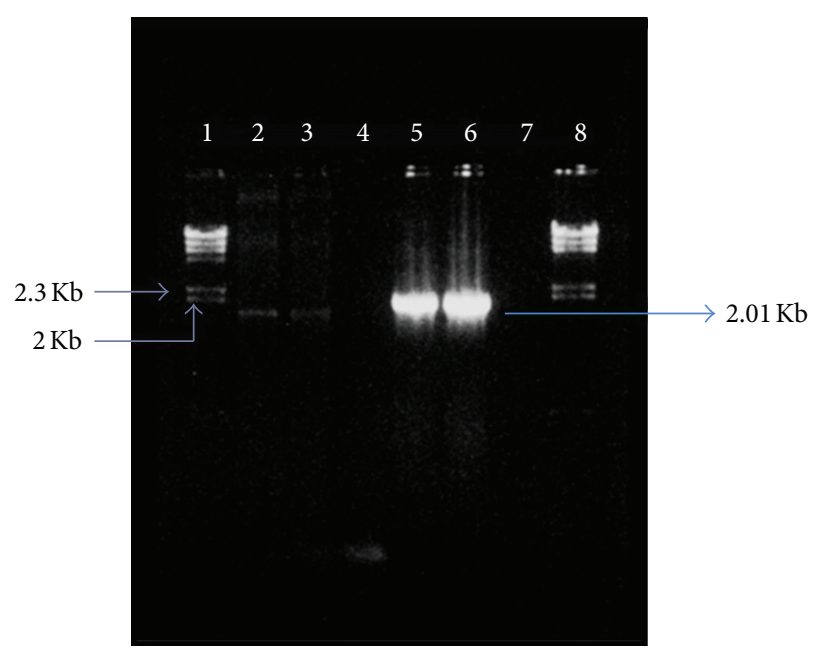

FIGURE 2: PCR amplification and confirmation of gene colicin E2.

XylA promoter, secretion signal SlpA, cell wall anchoring domain of PrtP, and the chloramphenicol resistance gene (cat gene).

Plasmid pSL-ColE2 was constructed by inserting a $2.01 \mathrm{~kb}$ PCR amplicon obtained from pColE2-P9 DNA containing $c e a B$ and $c e i B$ into pSLP111.1 (Figure 1). Transformants containing pSL-ColE2 demonstrated inhibitory activity against the uropathogenic E. coli (Figure 1). The presence and orientation of the $c e a B$ and $c e i B$ insertion in pSL-ColE2 was verified by PCR (Figure 2).

3.2. Extracellular Expression of Colicin E2. L. brevis DT24 transformants harboring recombinant pSL-ColE2 were tested for extracellular expression in $500 \mathrm{~mL}$ of MRS broth. Transformant and control strains containing vector only were 


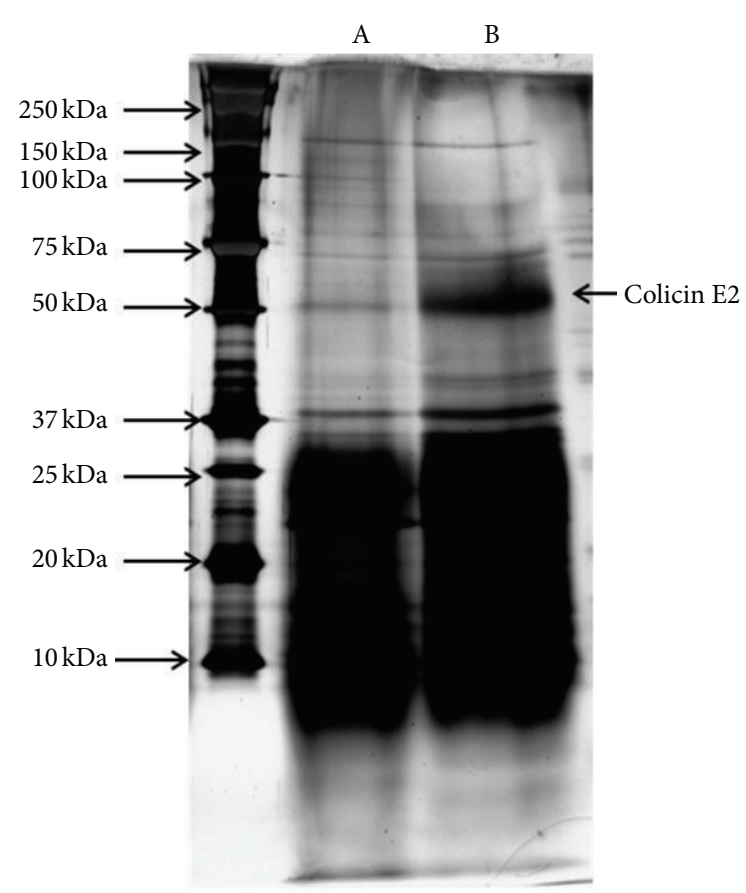

FIGURE 3: SDS-PAGE of ColE2 protein. (A) Total protein of L. brevis DT24 and (B) total protein of L. brevis DT24-Col E2. Colicin E2 arrow indicates extracellular secretion of ColE2 protein.

incubated with vigorous shaking (200 rpm), and cell growth was monitored by checking optical density at $600 \mathrm{~nm}$. After $24 \mathrm{hrs}$ of growth $52 \mathrm{kDa}$ protein was observed in SDS-PAGE analysis (Figure 3).

\subsection{Antimicrobial Activity of Recombinant L. brevis DT24} Expressing Colicin E2. Antimicrobial properties of transformed L. brevis DT24-ColE2 showed higher zone of inhibition $(56 \mathrm{~mm})$ compared to Wild Type L. brevis DT24 (23 mm) were shown in Figure 4. But there is no difference in the inhibition zone showed by L. brevis DT24 ColE2 and E. coli NCTC 50133.

\section{Discussion}

Various techniques have identified Lactobacillus species as the predominant microorganism found in the vaginas of most healthy and fertile women [40, 41]. Lactobacillus species have been studied as a potential probiotic for the prevention and treatment of urogenital disease in women [39-42]. During menstruation, the vaginal $\mathrm{pH}$ becomes neutral, most likely due to the influx of menses blood, which has a $\mathrm{pH}$ range of 6.9 to 7.2 which leads to lower Lactobacilli number in vagina and chances of infections like urinary tract infections and bacterial vaginosis.

Colicin E2 production by a nonpathogenic organism may have clinical applicability as a means to prevent catheterassociated urinary tract infection [22]. Evans et al. [54] demonstrated the possibility of developing oral whole-cell vaccines against diarrhea caused by enterotoxigenic E.coli

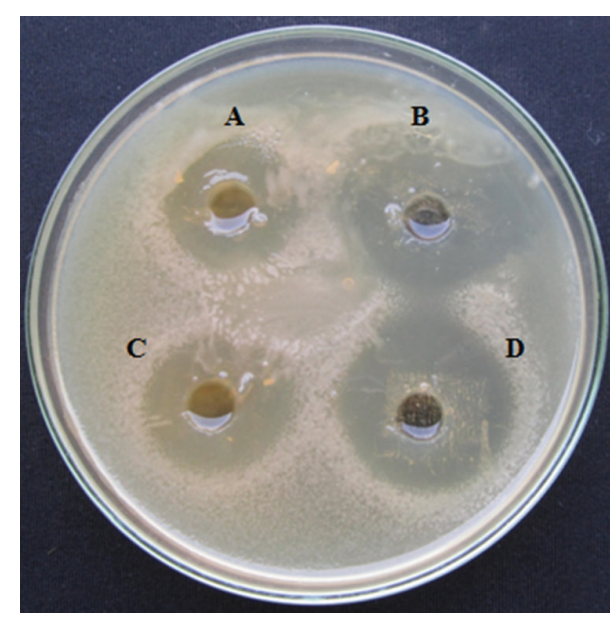
A. Lactobacillus brevis DT24
B. Lactobacillus brevis DT24-ColE2
C. Lactobacillus brevis DT24
D. E. coli NCTC 50133

FIGURE 4: Antimicrobial activity of $L$. brevis DT24-ColE2 cell-free supernatant against uropathogenic E. coli as an indicator strain.

by modifying this $E$. coli by the in situ destruction of chromosomal and plasmid DNAs by ColE2. The colicin operon is carried on a plasmid and includes a structural gene $(c e a B)$ encoding for the bacteriocin, an immunity gene (ceiB) that protects the producer cell from the toxin, and a lysis gene $(c e l B)$ that leads to death of the producer cell and release of ColE2 into the surrounding medium [23]. Sensitivity of gram-negative microorganisms to ColE2 is conferred by the binding of the bacteriocin to an outer membrane receptor, the TonB-dependent vitamin B12 transporter, BtuB [23]. After transport across the membrane, ColE2 acts as an endonuclease, degrading the DNA of the sensitive cell. During UTIs uropathogenic E. coli overexpresses surface protein BtuB which can act as receptor for binding colicin E2.

The colicin E2 gene (ColE2) from E. coli cloned in shuttle secretion vector (pSLP111.3) and successfully expressed in our lab probiotic isolate Lactobacillus brevis DT24 and its impact on the inhibitory activity of host organism were examined. The expression of ColE2 in Lactobacillus brevis DT24 was studied by isolating proteins extracellularly.

One of the challenges of transforming ColE2 in Lactobacillus is the differences in the transport mechanisms of bacteriocins in gram-negative and gram-positive microorganisms [55]. In gram-negative microorganisms, ColE2 is thought to be released into the surrounding medium after CelB-mediated lysis of the producer cell. Expression of $c e l B$ leads to changes in the cell envelope and results in activation of Omp LA, an outer membrane phospholipase A [23]. Mutation or deletion of the lysis protein has been shown to interfere with release, and in such cases, colicin remains in the cytoplasm [23]. In gram-positive microorganisms, secretion does not occur through cell lysis and is not a lethal event for the cell. Instead, secretion is dependent on a signal peptide, 
which typically contains conserved double-glycine regions and is mediated by a bacteriocin-specific transport system or the sec-dependent export pathway [56]. Although ColE2 does not contain a signal peptide to direct the secretion of the protein, it is predicted to contain 6 double-glycine regions at the $\mathrm{N}$ terminus, which may function in a manner analogous to a signal peptide. Thus, ColE2 may be secreted by a grampositive host without lysis of the producer cell. This feature is important if the genes encoding for colicin production are to be transferred to and expressed by a Lactobacillus [57].

This study demonstrated that genes associated with bacteriocin production from a gram-negative microorganism could be cloned, expressed, and secreted by a gram-positive microorganism in the absence of a lysis protein (CelB) and with addition of a signal peptide. In the present work, genes associated with ColE2 production $(c e a B$ and $c e i B)$ were transferred to L. brevis DT24, probiotic isolate from vagina. The level of ColE2 production by the colicin-producing transformants of $L$. brevis DT24 was similar to that of E. coli NCTC 50133, from which the ColE2-encoding genes (pColE2-P9) were derived.

Secretion of ColE2 proteins into the surrounding medium by E. coli NCTC 50133 and the pSLP111.3-ColE2 transformants occurred before cell leakage was observed. The mechanism proposed for secretion of ColE2 from E. coli involves release of the colicin caused by the lysis protein CelB [58-63]. Braun et al. [64] found that inactivation of $c e l B$ resulted in decreased release of colicin from the cells, compared with cells containing intact celB.

Cloning and expression of ColE2 in L. brevis DT24 allowed evaluation of the transformant as a bioactive compound for use in treatment of UTI. Similar strategies were used for treatment of Staphylococcus aureus infection by expressing antimicrobial protein lysostaphin in vaginal probiotic Lactobacillus plantarum WCFS1 [65] and inhibition of HIV by expressing anti-HIV proteins which were capable of blocking the HIV entry into human peripheral blood mononuclear cells in probiotic organism Lactobacillus reuteri RC-14 [66].

\section{Conclusion}

This study has demonstrated that the expression of E. coli colicin E2 (ColE2) into Lactobacillus showed increased expression of colicin E2 in extracellular level to inhibit the infectious disease occurred by uropathogenic E. coli. The probiotic properties of host Lactobacillus brevis DT24 were increased in the terms of antimicrobial activity against pathogenic $E$. coli. Oral administration of probiotics has clear effects on the numbers and activities of intestinal and fecal bacteria. The administration oral probiotics help to reduce the transfer of yeast and urogenital pathogenic bacteria from the rectum to vagina [67]. It may be possible to use these L. brevis DT24ColE2 probiotics in biotherapy (i.e., as vehicles for the secretion of colicin E2 in the gastrointestinal tracts as well as urovaginal tract for the treatment of UTI as well as other gastrointestinal infectious diseases).

\section{Conflict of Interests}

The authors declare that there is no conflict of interests regarding the publication of this paper.

\section{Acknowledgments}

The authors are thankful to Nirma Education and Research Foundation (NERF), Ahmedabad, for providing infrastructure and financial support. The authors also wish to thank Jos Seegers (Lactrys Biopharmaceuticals, The Netherlands) and E. coli Genetic Resource center (Yale University) for providing vector pSLP111.3 and the bacterial strain E. coli NCTC 50133.

\section{References}

[1] E. J. Dielubanza and A. J. Schaeffer, "Urinary tract infections in women," Medical Clinics of North America, vol. 95, no. 1, pp. 2741, 2011.

[2] B. Foxman, R. Barlow, H. D’Arcy, B. Gillespie, and J. D. Sobel, "Urinary tract infection: self-reported incidence and associated costs," Annals of Epidemiology, vol. 10, no. 8, pp. 509-515, 2000.

[3] L. E. Nicolle, "Uncomplicated urinary tract infection in adults including uncomplicated pyelonephritis," Urologic Clinics of North America, vol. 35, no. 1, pp. 1-12, 2008.

[4] D. E. Neal Jr., "Complicated urinary tract infections," Urologic Clinics of North America, vol. 35, no. 1, pp. 13-22, 2008.

[5] B. Foxman, "Recurring urinary tract infection: incidence and risk factors," The American Journal of Public Health, vol. 80, no. 3, pp. 331-333, 1990.

[6] R. Ikäheimo, A. Siitonen, T. Heiskanen et al., "Recurrence of urinary tract infection in a primary care setting: analysis of a 1year follow-up of 179 women," Clinical Infectious Diseases, vol. 22, no. 1, pp. 91-99, 1996.

[7] M. S. Litwin and C. S. Saigal, "Urologic diseases in America," NIH Publication 07-5512, US Department of Health and Human Services, Public Health Service, National Institutes of Health, National Institute of Diabetes and Digestive and Kidney Diseases, US Government Printing Office, Washington, DC, USA, 2007.

[8] J. E. Delzell and M. L. Lefevre, "Urinary tract infections during pregnancy," American Family Physician, vol. 61, no. 3, pp. 713721, 2000.

[9] R. N. Jones, K. C. Kugler, M. A. Pfaller, and P. L. Winokur, "Characteristics of pathogens causing urinary tract infections in hospitals in North America: results from the SENTRY Antimicrobial Surveillance Program, 1997," Diagnostic Microbiology and Infectious Disease, vol. 35, no. 1, pp. 55-63, 1999.

[10] G. G. Zhanel, J. A. Karlowsky, G. K. M. Harding et al., "A Canadian national surveillance study of urinary tract isolates from outpatients: comparison of the activities of trimethoprim-sulfamethoxazole, ampicillin, mecillinam, nitrofurantoin, and ciprofloxacin," Antimicrobial Agents and Chemotherapy, vol. 44, no. 4, pp. 1089-1092, 2000.

[11] I. Connell, W. Agace, P. Klemm, M. Schembri, S. Mårild, and C. Svanborg, "Type 1 fimbrial expression enhances Escherichia coli virulence for the urinary tract," Proceedings of the National Academy of Sciences of the United States of America, vol. 93, no. 18, pp. 9827-9832, 1996. 
[12] J. A. Roberts, B. I. Marklund, D. Ilver et al., "The Gal( $\alpha 1-4)$ Galspecific tip adhesin of Escherichia coli P-fimbriae is needed for pyelonephritis to occur in the normal urinary tract," Proceedings of the National Academy of Sciences of the United States of America, vol. 91, no. 25, pp. 11889-11893, 1994.

[13] P. Goluszko, S. L. Moseley, L. D. Truong et al., "Development of experimental model of chronic pyelonephritis with Escherichia coli O75:K5:H-bearing Dr fimbriae: mutation in the dra region prevented tubulointerstitial nephritis," The Journal of Clinical Investigation, vol. 99, no. 7, pp. 1662-1672, 1997.

[14] J. F. van den Bosch, L. Emödy, and I. Kétyi, "Virulence of haemolytic strains of Escherichia coli in various animal models," FEMS Microbiology Letters, vol. 13, no. 4, pp. 427-430, 1982.

[15] R. A. Welch, E. P. Dellinger, B. Minshew, and S. Falkow, "Haemolysin contributes to virulence of extra-intestinal E. coli infections," Nature, vol. 294, no. 5842, pp. 665-667, 1981.

[16] K. E. Rippere-Lampe, A. D. O'Brien, R. Conran, and H. A. Lockman, "Mutation of the gene encoding cytotoxic necrotizing factor type $1\left(c n f_{1}\right)$ attenuates the virulence of uropathogenic Escherichia coli," Infection and Immunity, vol. 69, no. 6, pp. 3954-3964, 2001.

[17] M. C. Lane, V. Lockatell, G. Monterosso et al., "Role of motility in the colonization of uropathogenic Escherichia coli in the urinary tract," Infection and Immunity, vol. 73, no. 11, pp. 76447656, 2005.

[18] F. K. Bahrani-Mougeot, E. L. Buckles, C. V. Lockatell et al., "Type 1 fimbriae and extracellular polysaccharides are preeminent uropathogenic Escherichia coli virulence determinants in the murine urinary tract," Molecular Microbiology, vol. 45, no. 4, pp. 1079-1093, 2002.

[19] J. D. Schilling, M. A. Mulvey, C. D. Vincent, R. G. Lorenz, and S. J. Hultgren, "Bacterial invasion augments epithelial cytokine responses to Escherichia coli through a lipopolysaccharidedependent mechanism," The Journal of Immunology, vol. 166, no. 2, pp. 1148-1155, 2001.

[20] A. G. Torres, P. Redford, R. A. Welch, and S. M. Payne, “TonBdependent systems of uropathogenic Escherichia coli aerobactin and heme transport and TonB are required for virulence in the mouse," Infection and Immunity, vol. 69, no. 10, pp. 6179-6185, 2001.

[21] E. C. Hagan and H. L. T. Mobley, "Uropathogenic Escherichia coli outer membrane antigens expressed during urinary tract infection," Infection and Immunity, vol. 75, no. 8, pp. 3941-3949, 2007.

[22] B. W. Trautner, R. A. Hull, and R. O. Darouiche, "Colicins prevent colonization of urinary catheters," Journal of Antimicrobial Chemotherapy, vol. 56, no. 2, pp. 413-415, 2005.

[23] E. Cascales, S. K. Buchanan, D. Duché et al., "Colicin biology," Microbiology and Molecular Biology Reviews, vol. 71, no. 1, pp. 158-229, 2007.

[24] K. Gupta, D. Scholes, and W. E. Stamm, "Increasing prevalence of antimicrobial resistance among uropathogens causing acute uncomplicated cystitis in women," The Journal of the American Medical Association, vol. 281, no. 8, pp. 736-738, 1999.

[25] J. D. D. Pitout, P. Nordmann, K. B. Laupland, and L. Poirel, "Emergence of Enterobacteriaceae producing extended-spectrum $\beta$-lactamases (ESBLs) in the community," Journal of Antimicrobial Chemotherapy, vol. 56, no. 1, pp. 52-59, 2005.

[26] J. Rodriguez-Baño and D. L. Paterson, "A change in the epidemiology of infections due to extended-spectrum $\beta$-lactamaseproducing organisms," Clinical Infectious Diseases, vol. 42, no. 7, pp. 935-937, 2006.
[27] D. L. Paterson and R. A. Bonomo, "Extended-spectrum $\beta$ lactamases: a clinical update," Clinical Microbiology Reviews, vol. 18, no. 4, pp. 657-686, 2005.

[28] J. D. D. Pitout and K. B. Laupland, "Extended-spectrum $\beta$ lactamase-producing Enterobacteriaceae: an emerging publichealth concern," The Lancet Infectious Diseases, vol. 8, no. 3, pp. 159-166, 2008.

[29] M. A. D. Antonio, S. E. Hawes, and S. L. Hillier, "The identification of vaginal Lactobacillus species and the demographic and microbiologic characteristics of women colonized by these species," The Journal of Infectious Diseases, vol. 180, no. 6, pp. 1950-1956, 1999.

[30] B. Aslim and E. Kilic, "Some probiotic properties of vaginal Lactobacilli isolated from healthy women," Japanese Journal of Infectious Diseases, vol. 59, no. 4, pp. 249-253, 2006.

[31] R. A. MacPhee, R. Hummelen, J. E. Bisanz, W. L. Miller, and G. Reid, "Probiotic strategies for the treatment and prevention of bacterial vaginosis," Expert Opinion on Pharmacotherapy, vol. 11, no. 18, pp. 2985-2995, 2010.

[32] W. M. Russell and T. R. Klaenhammer, "Efficient system for directed integration into the Lactobacillus acidophilus and Lactobacillus gasseri chromosomes via homologous recombination," Applied and Environmental Microbiology, vol. 67, no. 9, pp. 4361-4364, 2001.

[33] M. Zozaya-Hinchliffe, R. Lillis, D. H. Martin, and M. J. Ferris, "Quantitative PCR assessments of bacterial species in women with and without bacterial vaginosis," Journal of Clinical Microbiology, vol. 48, no. 5, pp. 1812-1819, 2010.

[34] C. A. Elkins, M. E. Muñoz, L. B. Mullis, R. L. Stingley, and M. E. Hart, "Lactobacillus-mediated inhibition of clinical toxic shock syndrome Staphylococcus aureus strains and its relation to acid and peroxide production," Anaerobe, vol. 14, no. 5, pp. 261-267, 2008.

[35] J. M. Laughton, E. Devillard, D. E. Heinrichs, G. Reid, and J. K. McCormick, "Inhibition of expression of a staphylococcal superantigen-like protein by a soluble factor from Lactobacillus reuteri," Microbiology, vol. 152, no. 4, pp. 1155-1167, 2006.

[36] V. S. Ocaña, A. A. P. de Ruiz Holgado, and M. E. Nader-Macías, "Characterization of a bacteriocin-like substance produced by a vaginal Lactobacillus salivarius strain," Applied and Environmental Microbiology, vol. 65, no. 12, pp. 5631-5635, 1999.

[37] J. Osset, R. M. Bartolomé, E. García, and A. Andreu, "Assessment of the capacity of Lactobacillus to inhibit the growth of uropathogens and block their adhesion to vaginal epithelial cells," The Journal of Infectious Diseases, vol. 183, no. 3, pp. 485491, 2001.

[38] M. C. Otero and M. E. Nader-Macías, "Inhibition of Staphylococcus aureus by $\mathrm{H}_{2} \mathrm{O}_{2}$-producing Lactobacillus gasseri isolated from the vaginal tract of cattle," Animal Reproduction Science, vol. 96, no. 1, pp. 35-46, 2006.

[39] M. E. Falagas, G. I. Betsi, and S. Athanasiou, "Probiotics for the treatment of women with bacterial vaginosis," Clinical Microbiology and Infection, vol. 13, no. 7, pp. 657-664, 2007.

[40] V. Redondo-Lopez, R. L. Cook, and J. D. Sobel, "Emerging role of lactobacilli in the control and maintenance of the vaginal bacterial microflora," Reviews of Infectious Diseases, vol. 12, no. 5, pp. 856-872, 1990.

[41] G. Reid, J. Dols, and W. Miller, "Targeting the vaginal microbiota with probiotics as a means to counteract infections," Current Opinion in Clinical Nutrition and Metabolic Care, vol. 12, no. 6, pp. 583-587, 2009. 
[42] G. Reid, J. Jass, M. T. Sebulsky, and J. K. McCormick, "Potential uses of probiotics in clinical practice," Clinical Microbiology Reviews, vol. 16, no. 4, pp. 658-672, 2003.

[43] F. K. Beller and K. W. Schweppe, "Review on the biology of menstrual blood," in The Biology of the Fluids of the Female Genital Tract, F. K. Beller and G. G. B. Schumacher, Eds., pp. 231-245, North-Holland, New York, NY, USA, 1979.

[44] D. R. Hill, M. E. Brunner, D. C. Schmitz et al., "In vivo assessment of human vaginal oxygen and carbon dioxide levels during and post menses," Journal of Applied Physiology, vol. 99, no. 4, pp. 1582-1591, 2005.

[45] G. L. D. S. Santiago, P. Cools, H. Verstraelen et al., "Longitudinal study of the dynamics of vaginal microflora during two consecutive menstrual cycles," PLoS ONE, vol. 6, no. 11, Article ID e28180, 2011.

[46] F. E. A. Keane, C. A. Ison, and D. Taylor-Robinson, "A longitudinal study of the vaginal flora over a menstrual cycle," International Journal of STD and AIDS, vol. 8, no. 8, pp. 489494, 1997.

[47] D. A. Eschenbach, S. S. Thwin, D. L. Patton et al., "Influence of the normal menstrual cycle on vaginal tissue, discharge, and microflora," Clinical Infectious Diseases, vol. 30, no. 6, pp. 901907, 2000

[48] S. Srinivasan, C. Liu, C. M. Mitchell et al., “Temporal variability of human vaginal bacteria and relationship with bacterial vaginosis," PLoS ONE, vol. 5, no. 4, Article ID e10197, 2010.

[49] J. Sambrook, E. F. Fritsch, and T. Maniatis, Molecular Cloning: A Laboratory Manual, Cold Spring Harbor Laboratory, Cold Spring Harbor, NY, USA, 2nd edition, 1989.

[50] S. E. Murinda, R. F. Roberts, and R. A. Wilson, "Evaluation of colicins for inhibitory activity against diarrheagenic Escherichia coli strains, including serotype O157:H7," Applied and Environmental Microbiology, vol. 62, no. 9, pp. 3196-3202, 1996.

[51] J. Aarnikunnas, N. von Weymarn, K. Rönnholm, M. Leisola, and A. Palva, "Metabolic engineering of Lactobacillus fermentum for production of mannitol and pure L-lactic acid or pyruvate," Biotechnology and Bioengineering, vol. 82, no. 6, pp. 653-663, 2003.

[52] R. W. Jack, J. R. Tagg, and B. Ray, "Bacteriocins of gram-positive bacteria," Microbiological Reviews, vol. 59, no. 2, pp. 171-200, 1995.

[53] U. K. Laemmli, "Cleavage of structural proteins during the assembly of the head of bacteriophage T4," Nature, vol. 227, pp. 680-685, 1970.

[54] D. J. Evans Jr., D. G. Evans, A. R. Opekun, and D. Y. Graham, "Immunoprotective oral whole cell vaccine for enterotoxigenic Escherichia coli diarrhea prepared by in situ destruction of chromosomal and plasmid DNA with colicin E2," FEMS Microbiology Immunology, vol. 1, no. 1, pp. 9-18, 1988.

[55] E. Cascales, S. K. Buchanan, D. Duché et al., "Colicin biology," Microbiology and Molecular Biology Reviews, vol. 71, no. 1, pp. 158-229, 2007.

[56] L. O'Sullivan, R. P. Ross, and C. Hill, "Potential of bacteriocinproducing lactic acid bacteria for improvements in food safety and quality," Biochimie, vol. 84, no. 5-6, pp. 593-604, 2002.

[57] C. Wandersman, "Secretion across the bacterial outer membrane," Trends in Genetics, vol. 8, no. 9, pp. 317-322, 1992.

[58] A. P. Pugsley and J. P. Rosenbusch, "Release of colicin E2 from Escherichia coli," Journal of Bacteriology, vol. 147, no. 1, pp. 186192, 1981.
[59] A. P. Pugsley and M. Schwartz, "Expression of a gene in a 400base-pair fragment of colicin plasmid ColE2-P9 is sufficient to cause host cell lysis," Journal of Bacteriology, vol. 156, no. 1, pp. 109-114, 1983.

[60] A. P. Pugsley and M. Schwartz, "Colicin E2 release: lysis, leakage or secretion? Possible role of a phospholipase," The EMBO Journal, vol. 3, no. 10, pp. 2393-2397, 1984.

[61] S. T. Cole, B. Saint-Joanis, and A. P. Pugsley, "Molecular characterisation of the colicin E2 operon and identification of its products," Molecular and General Genetics, vol. 198, no. 3, pp. 465-472, 1985.

[62] S. Kanoh, H. Masaki, S. Yajima, T. Ohta, and T. Uozumi, "Signal peptide of the colicin E2 lysis protein causes host cell death," Agricultural and Biological Chemistry, vol. 55, no. 6, pp. 16071614, 1991.

[63] D. Cavard and B. Oudega, "General introduction to the secretion of bacteriocins," in Bacteriocins, Microcins, and Lantibiotics, R. James, C. Lazdunski, and F. Pattus, Eds., pp. 297-305, Springer, Berlin, Germany, 1992.

[64] V. Braun, H. Pilsl, and P. Gross, "Colicins: structures, modes of action, transfer through membranes, and evolution," Archives of Microbiology, vol. 161, no. 3, pp. 199-206, 1994.

[65] H. Liu, Y. Gao, L.-R. Yu, R. C. Jones, C. A. Elkins, and M. E. Hart, "Inhibition of Staphylococcus aureus by lysostaphin-expressing Lactobacillus plantarum WCFS1 in a modified genital tract secretion medium," Applied and Environmental Microbiology, vol. 77, no. 24, pp. 8500-8508, 2011.

[66] J. J. Liu, G. Reid, Y. Jiang, M. S. Turner, and C.-C. Tsai, "Activity of HIV entry and fusion inhibitors expressed by the human vaginal colonizing probiotic Lactobacillus reuteri RC-14," Cellular Microbiology, vol. 9, no. 1, pp. 120-130, 2007.

[67] G. Reid, D. Charbonneau, J. Erb et al., "Oral use of Lactobacillus rhamnosus GR-1 and L. fermentum RC-14 significantly alters vaginal flora: randomized, placebo-controlled trial in 64 healthy women," FEMS Immunology and Medical Microbiology, vol. 35, no. 2, pp. 131-134, 2003. 


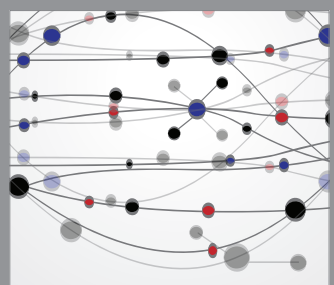

The Scientific World Journal
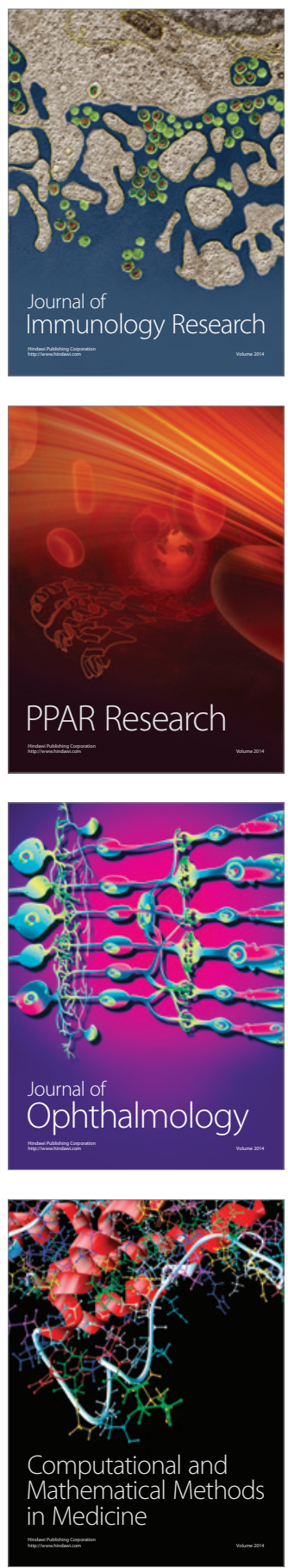

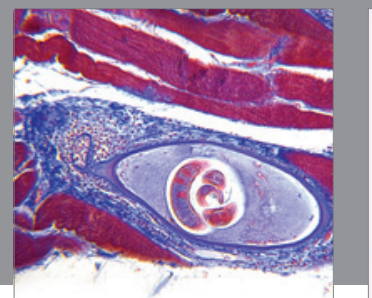

Gastroenterology

Research and Practice
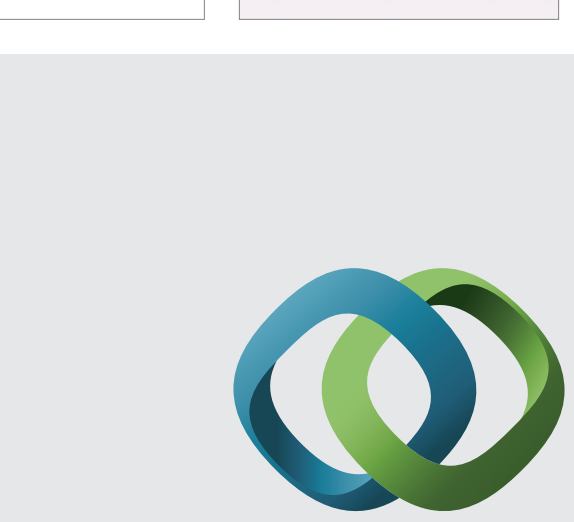

\section{Hindawi}

Submit your manuscripts at

http://www.hindawi.com
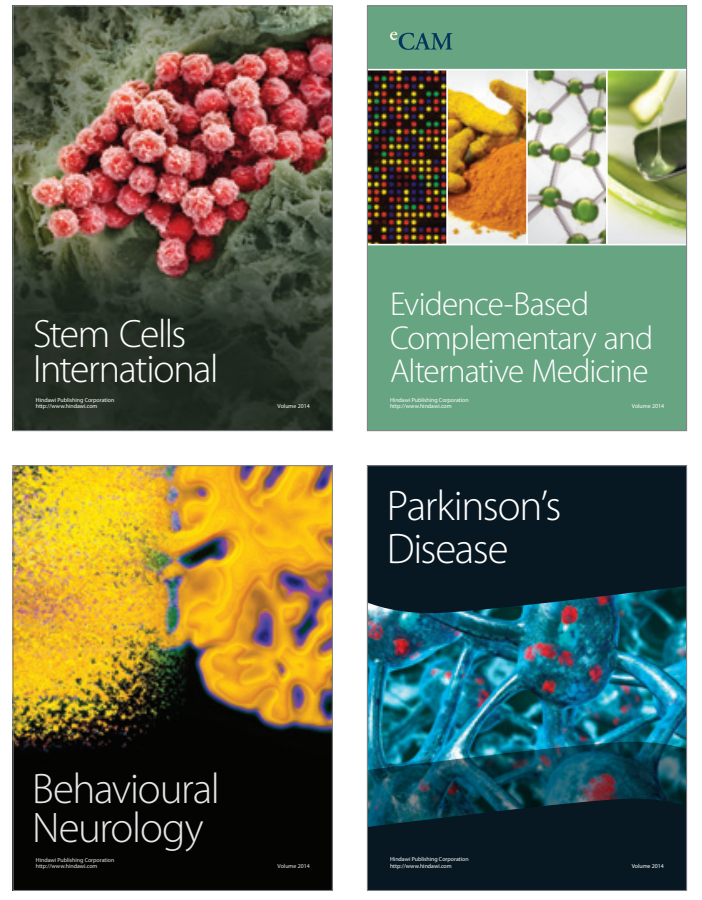
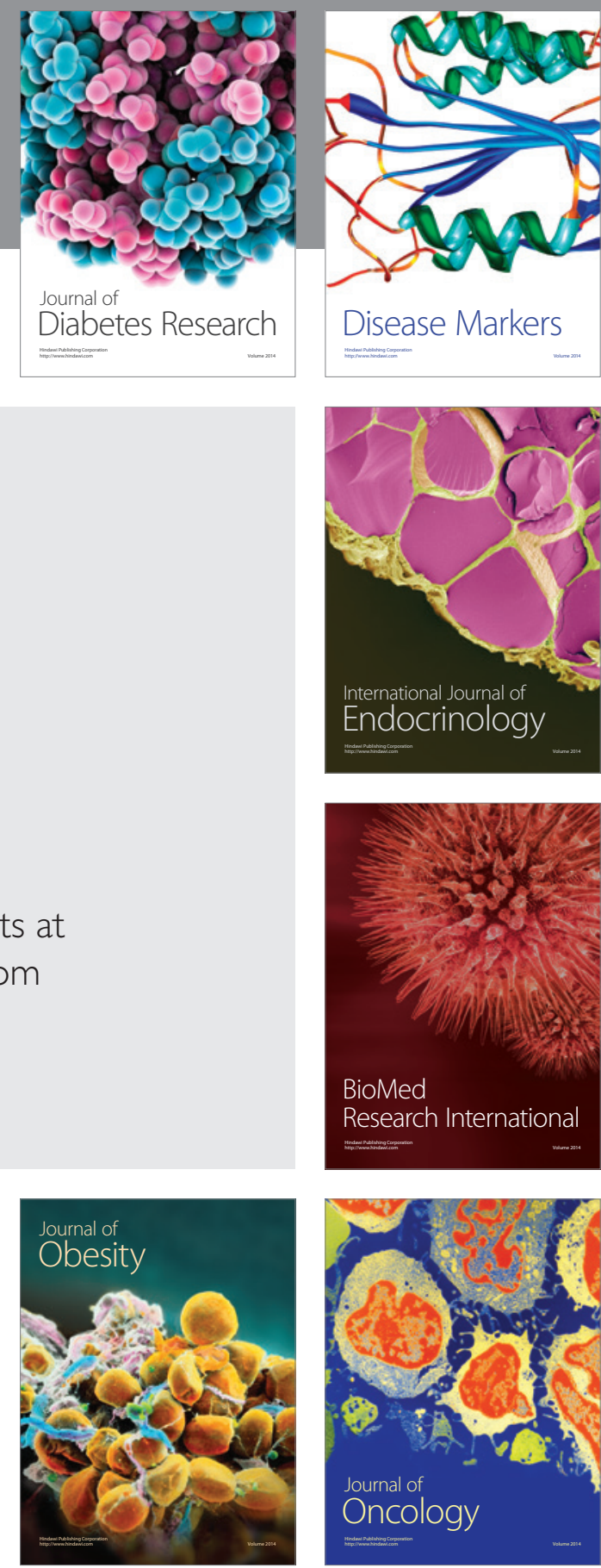

Disease Markers
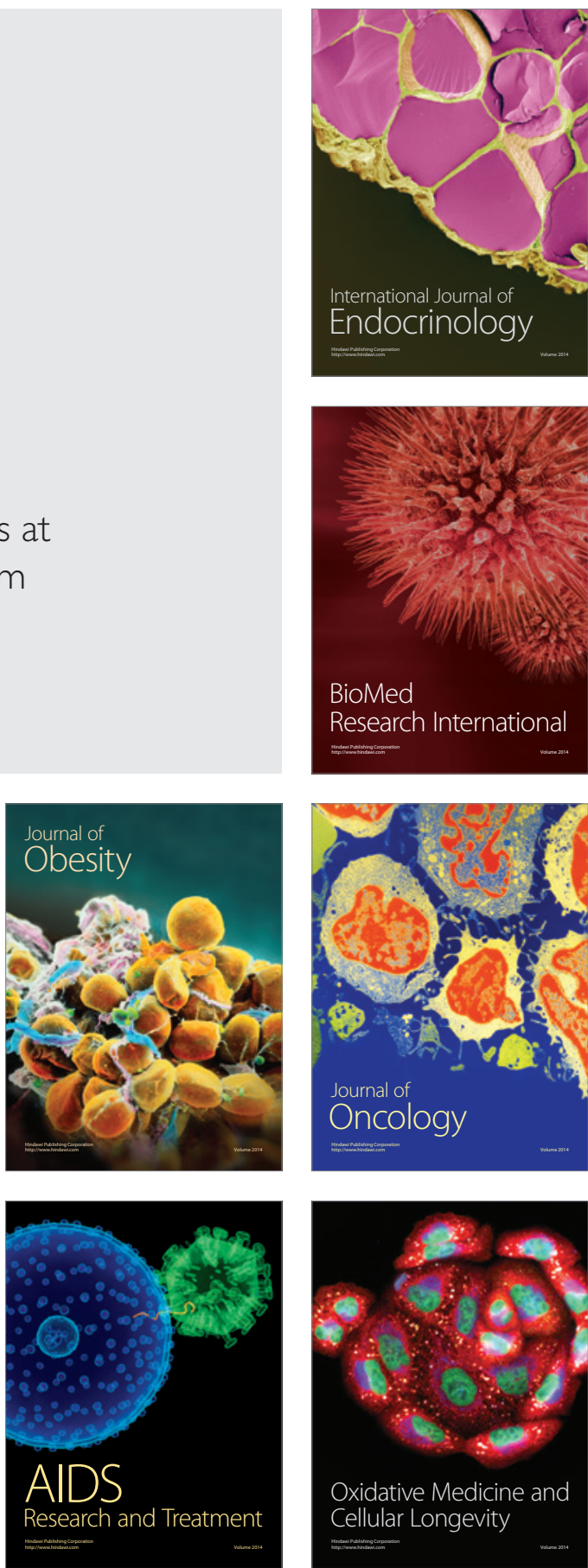